\title{
Imagining the I-You through embodied writing
}

\begin{abstract}
Deep understanding resides in our bodies. To understand is to draw on the sensations on your skin, in your bones and in the pit of your stomach. It is to feel the pain and suffering of others, as if it is experienced by your own body. In times of social unrest and division, embodied understanding, rather than logical rationalisation, becomes paramount. Embodied understanding minimises divisiveness and demolishes the borders that create a sense of otherness. To understand is to imaginatively enter the bodily experiences of others and to become accountable to their suffering. As academic writers, we have the responsibility to cultivate embodied ways of knowing by writing reflexively about our practices and depicting them in rich sensorial ways.
\end{abstract}

\section{Us and Them}

Emerging from lockdown. So much has happened and we have not yet processed it all. Rather than talking of work, we speak from our emotions. "It has been one thing after another. I don't think I can endure anymore," says one colleague. It was easy to commiserate. Things had been hard for a long time. Emotions had run ragged for more than a year with people fighting the fires, seeking refuge from air thickened with ash, enduring the storms that had brought long power outages, only to find themselves fighting the health and economic crisis that had come with pandemic. And now, the protests sparked by the death of George Floyd were rocking cities around the world, threatening the recovery of societies barely emerging from the COVID-19 lockdown. The thought of going back under lockdown was. . . unthinkable. Normality was embryonic, held there by a painful one step forward and a potentially two steps back recovery process. No wonder people had desired some peace and quiet, and for the world to go back to normal, whatever that had meant. Why can't things go back to normal? The question hung in the air until it was broken.

"I was thinking of taking my children to the protests," a voice interjects. We all turn our heads in its direction. The voice belonged to my fair skinned friend with an indigenous heritage. Her adolescent children had begun asking questions about colour and race. Their skin was slightly darker than hers. Olive. They had noticed the confusion on the faces of strangers when they were spoken to, and sensed that others needed to position their bodies to engage them. I watched her carefully masked face, knowing the inner war that was waging. The same pressure was building inside me, of being spoken about, without the conversation being directed at me, helplessly complicit, and confused about where I stood. My ethnic body, joining me to the protesters in ways that words could not explain, but at the same time, made privy to an 'us' against 'them' narrative. The unspoken criticism hurt. With zero community transmissions for a week, our community had turned a corner with the COVID 19 outbreak. Considering what was at stake, the broader social message was to turn a blind eye.

Never to back down from her beliefs, my friend speaks again. "Rather than thinking about it as a disruption of normal life, maybe we should think about it as an opportunity to finally right a wrong. Can you imagine what people must have gone through to take to the streets during such times?" Can you imagine? 


\section{That's just our coloured skin ...}

I close my eyes and try to imagine. The memories are not so distant, and the bodily sensations feel like yesterday. The consciousness of the body's visibility, through almond shaped eyes, olive coloured skin and jet-black hair, is forever present, as well as the awareness of the reactions that these bodily markings could provoke. My experience may pale compared to others, and yet, my body still remembers.

First, the venom takes you away by surprise, it is the random abuse from a person passing by that catches you off guard. There is a helplessness in realising that it was nothing that I did. Then, there is a realisation that my mere presence is offensive. There is nothing you could have done differently. The taunts, when they come, don't make any sense. I am told to go back to my country, but I think, where is my home? I left my country of origin almost forty years ago. The shame of being asked by well-meaning people about why your English is 'so good.' I have lived in an English speaking for virtually all my life. Or the hyper-alertness that remains even as you walk down the street, conscious of being cut down just by looking a certain way. When a stranger wearing a patterned shirt rammed his body against me so hard that my breath was knocked out of my body, I was shaken. He had deliberately tensed his muscles as he rushed past me, making his body like a rock, to inflict hurt. What did I do to provoke it? He had rolled over me, as if I had not existed. My body had not even deserved the space it occupied. These encounters are all bottled up until the scales become tipped, and a blind anger spills out. Enough! Enough! Enough! The spark fuses with a deeper well of stored pain caused by being made to feel unsafe in your own skin. Never completely safe, and never set free from the baggage of hurt that floats like an iceberg in your consciousness.

What will it take for you to imagine? My friend caught me in the corridor the next day, relating her discomfort at the conversation that took place. "What will it take for others to imagine the experience of the protesters?" she had asked. I looked at her and did not speak. Both of us knew the answer in our bodies. Although she was visibly white, she had had to fight on the behalf of her darker coloured family members. She understood the pain of having bodies that automatically place you on a lower footing, which makes you acutely aware of life's uneven playing field. This awareness had made us both fierce, wary and worn. "Unless they have experienced the shock or the fear in their own bodies. ..," I reply, not needing to complete the sentence she has already filled in her mind. She nods. Unless you have registered the fear on your skin and in your racing heart, it can be hard to relate. To imagine the hardship of another person is like feeling the pain in your own body, in the way you inhale the distresses of your offspring. It is understanding in its acutest form.

It is strangely comforting to see my thoughts externalised by others. One Indigenous Aboriginal man in Australia describes the protests as an opportunity to be finally heard (Semmler, 2020). He sees the Black Lives Matter movement as an opportunity for the voices of Indigenous Australians to be finally listened to or understood, rather than simply acknowledged. He explains how listening involves an attempt to comprehend the real pain felt by the bodies of the Indigenous Australians, as if it were your own. He believes that these protests are vital to prevent history from repeating itself, and for teaching the younger generations of Indigenous Australians that they have a voice and can speak out. I am struck by the voice of one eight year old boy, who is the same age as my eldest child and who simply states, "Black lives 
really do matter, we're not doing any crime or anything, that's just our coloured skin" (Semmler, 2020, para. 18). His words make me wonder whether my own child would have made a similar comment, knowing that I have tried my best to shield him. It's not a crime. . that's just our coloured skin. I had not wanted him to know that the colour of his skin could ever have such associations. His beautiful little body, so full of the hope of a vibrant life. Who would cast a shadow? Perhaps, if it were a matter of survival.

\section{The 'I-It' and 'I-You'}

The talk continues and I feel myself pushed up against a wall of rigid thoughts and limited imagination. There is a sense of $u s$ vs them, as the motivations behind actions were acknowledged, but not understood. What would it take to help someone imagine otherwise? Thoughts of this divide draws me to the literature of Martin Buber (1958), who introduced the perspectives of the 'I-It' and the 'I-You.' Buber (1958) described the I as the ego that is conscious of itself through, ". . sett[ing] [itself] apart from other egos," and seeks to equally control the other by superficially breaking it up matter into small and isolated categories (Buber, 1958, p. 111). He explained how the 'I-It' or ego orientated view fragments our perceptions of reality by drawing false boundaries, which creates a divide and conquer mindset and the need to prove superiority (Miller, 2000; Palmer, 1983). This perspective diminishes all those involved, as the knower is dehumanized and the other is also rendered as a lifeless object to manipulate and control (Neill, 1994). The I-It manifests when a person indirectly objectifies their worldview by making it fixed and incapable of being challenged and broadened (Palmer, 1983). An individual, who cannot look beyond their own thought processes to empathize with another, discounts the life inherent within the other. They lose the capacity to imagine and a part of their humanity dies in the process.

The $I t$ is without stirrings of emotion, which is our human counterpart. The photographer Devin Allen highlights this point as he observes the face of the police officer kneeling on George Floyd's neck, and remarks, ". . . it was just so mute. There was no emotion in it" (Sara, 2020, para. 28). No emotion is caught on his face, as he slowly asphyxiates a man who pleads for his life. It is a telling detail. He lacked emotion, despite being the cause of another's shame and suffering. There was no self-doubt, hesitation or thoughts of pulling back. Something core was this missing element from his face, which could have averted tragedy. What was a human life worth to him, to be so emotionless? Had his capacity for imagination retreated so far?

Boundless imagination resides in the I-You encounter. The You is beheld where it stands, as "no thing among things, no event among events; it was present exclusively" (Buber, 1958, p. 89). Unlike the limiting one-sided relationship of the I-It, the I-You is a mutual encounter in which the presence of both the knower and the other is enhanced, as the, " . . I and You confront each other freely in a reciprocity that is not involved in or tainted by any causality; here man (sic) finds guaranteed the freedom of his being and of being" (Buber, 1958, p.89). To behold and to see the other as it reveals itself, and to enter into a relationship with it, allowing the other to be completely free in their own being. Difference does not form lines of division that separates, categorises and allocates value, but the uniqueness of the other becomes a precious catalyst. Conversations evolve and new learning takes place as multiple fields of reference fuse to enlarge one's sense of the world. 
There is a natural harmony in our bodies. This unity can be seen in a photo taken of Patrick Hutchinson, who rescues a counter-protester from the far right in the London Black Lives Matter protests. In the photo the viewer immediately focuses on two bodies. One belongs to a black protestor; the other is of the injured white counter-protester who he is carrying to safety ("Patrick Hutchinson," 2020). There is a look of exhaustion in Hutchinson's eyes, as he pushes his body forward, surrounded by the din and noise of other angry bodies. His muscles strain under the heavy weight of a white protester, who lies limply on his shoulder. The pale skin of the injured man's body is a stark comparison to the darker chocolate brown hues of Hutchinson's face and arms. The look in both their eyes carry the intensity of being lost at sea; they are two bodies just keeping afloat. One appears able-bodied and strong; the other is barely clinging on with one arm and shielding his injured head with the other. Their different coloured bodies are separated by a centuries old divide, but reduced to their humanness, they are two bodies without colour. The rescuer bridges the gap as he shelters the "human being on the floor," regardless of the divisive clashes that continue to rage on around them ("Patrick Hutchinson," 2020, para. 27). They are two bodies pulsating with life, finding each other in a time of need, complementary in their guardianship roles. With the warmth of our bodies, we are made to offer shelter, regardless of colour.

\section{The primary of lived experience}

The authenticity and authority of lived experience is undeniable. It covers the hard to reach grooves and crevices of human experience, the kind of complexities that can only be verified through the resonance. In recounting his experiences of the April 2015 protest in Baltimore, sparked by the death of Freddie Gray, a young black man who had died in police custody due to spinal injuries, Devin Allen took a photo of a protestor running away from the police that ended up on the cover of the Time magazine (Sara, 2000). The photo captures a lone man running away from a squad of riot police armed with batons. His face is covered with a balaclava, but from his athletic build and clothes, he looks no older than a college student. The photograph frames a picture of the unbalanced power between his lone unarmed body and the wave of heavily armed sea of uniformed police behind him. Allen's lens communicates a strong critique of the systematic imbalance of power and rights. His lived experience of injustice is caught in this frame, as Sara (2020) writes, "Devin didn't just know the story of young black men in the city, he'd lived it" (para. 9). To live something is to understand it in your bones, and to intuitively position your camera to take that symbolic shot. But rather than simply taking the photograph, Allen authors it by honing the lens onto what resonated with him, which was the life of a black man living on the streets. He understood this as he had lived it.

To write about what we know is to draw on our lived experiences. It is our most intimate form of knowledge. The one that we have the best insight into. Clure (2020) explains this point by writing about how his coverage of the Black Lives Matter protests is enhanced by his identity as a black reporter. Not only does his lived experiences resonate with those he seeks to report on, the thanks he receives for his report demonstrates the power of his body. It communicates messages that words cannot convey. Clure (2020) shares a text that he receives from his mother as she watches his broadcast, "Thank you for being a young black man in the world and country that sometimes doesn't see or understand you, and not letting that stop you from being who you are" (para. 41). He feels the call of his body to speak out on its splendid behalf. The knowledge it bears is intimate, and he cannot escape his connection to it, in the same way he 
cannot escape his own body. The connection doesn't diminish him, but amplifies his power, as it bears testament to the embodied experiences of others.

\section{The call of embodied writing}

If our life experiences do not bring us into contact with the other, the worlds that we enter through what we read, hear and see, can help us to imagine other ways of being. The aim of embodied writing is accordingly to help us to inhabit a rich emotional and reflexive world. Embodied writing, in particular, can help us to access other worlds through activating our physical senses and bringing us back to our core bodily ways of knowing the world. Through occupying the experiences of others through our body, it is possible to connect to them on this core level. Embodied writing provides us with the words and images to imagine what another person may be feeling deep within their bodies, as these physical sensations reverberate powerfully with affect. The lightness of our heels, the heaviness in the pits of our stomachs, the hollowness of our eye sockets or the warmth on our cheeks in the afternoon sunlight, are all messages we recognise on a primal level. They are familiar and provide a footing or a way to imagine the experiences of others. The term empathy, encompasses this capacity to go beyond one's world to enter that of another " to understand[ing], be[ing] aware of, be[ing] sensitive to, and vicariously experienc[e] the feelings, thoughts, and experience of another of either the past or present without having the feelings, thoughts, and experience fully communicated in an objectively explicit manner" (Merriam-Webster, n.d.a); there is also the imagination that creates a sense of oneness or "the imaginative projection of a subjective state into an object so that the object appears to be infused with it" (Merriam-Webster, n.d.-b).

Embodied writing helps others to imagine the lived experiences of others. To capture an experience as it is lived through the static lifeless words, is a difficult task. Embodied writers essentially need to craft life into the words that are retained within the lived moment. To do so, they need to be profoundly reflexive and be attuned to their emotional worlds so that they can pick up on their affect-laden encounters. To craft an encounter is to capture fleeting sensations through words that are as light and as full of life as the experiences themselves, like fresh moving air or a trickling stream of water, until nothing is retained but the felt-sense and the emotions that linger on. To convey a mood and feeling, as physically experienced by the body, is to enable a reader to imaginatively occupy another person's world, which may physically bear no resemblance to their own. Such imagination comes from a place of clarity. It does not draw divisive lines to prove superiority. It is not the stark internal desert of those who dehumanise others, and in doing so, dehumanise themselves. It is based instead on a mutual respect that enables dialogue and growth and draws you into the eternal and expansive core of our shared humanity (Palmer, 1983).

\section{Reference list}

Buber, M. (1958). I and Thou. New York: Charles Scribner's Sons.

Clure, E. (2020, June 13). ABC News journalist Elias Clure on racism and the importance of a black reporter covering a Black Lives Matter protest. ABC News. Retrieved from https://www.abc.net.au/news/about/backstory/2020-06-12/abc-elias-clure-black-reporter-black-livesmatter/12344448 
Merriam-Webster. (n.d.-a). Immaterial [Def. 1]. Retrieved June 15, 2020, from https://www.merriamwebster.com/dictionary/empathy

Merriam-Webster. (n.d.-b). Inspire [Def. 2]. Retrieved June 15, 2020, from https://www.merriamwebster.com/dictionary/empathy

Miller, J. (2000). Education and the Soul. Albany: State University of New York Press.

Neill, E. (1994). Unless you be as Little Children. Brisbane: Bolda-Lok Publishing and Educational Enterprises.

Palmer, P. (1983). To Know as We are Known: Education as a Spiritual Journey. San Francisco. Harper SanFrancisco.

Patrick Hutchinson, Black Lives Matter protester who carried opposing demonstrator to safety, says he wants 'equality for all of us. (2020, June 14). ABC News. Retrieved from

https://www.abc.net.au/news/2020-06-15/patrick-hutchinson-black-lives-matter-protester-photolondon/12354776

Sara, S. (2020, June 16). One photo from the Baltimore Black Lives Matter protests changed Devin Allen's life. Then the guilt nearly overcame him. ABC News. Retrieved from https://www.abc.net.au/news/2020-06-16/devin-allen-black-lives-matter-photographer/12355110

Semmler, E. (2020, June 14). Black Lives Matter message in central Queensland seen as a conversation that needs to happen. ABC News. Retrieved from https://www.abc.net.au/news/2020-06-14/black-livesmatter-message-in-central-queensland/12348032 